\title{
Traumatic avulsion of the optic nerve
}

\section{Traumatska avulzija optičkog nerva}

Katarina Janicijevic, Mirjana Janicijevic Petrovic, Sanja Kocic, Snezana Radovanovic

1. Faculty of Medical Sciences, University of Kragujevac, Kragujevac, Serbia

RECEIVED 04.11.2015

ACCEPTED 11.01 .2016 .
Katarina Janicijević, Mirjana Janicijević Petrović, Sanja Kocić, Snežana Radovanović

1. Fakultet medicinskih nauka, Univerzitet u Kragujevcu, Kragujevac

PRIMLJEN 04.11.2015.

PRIHVAĆEN 11.01.2016.

\begin{abstract}
Optic nerve avulsion is a very rare but an extremely devastating complication of the eye injuries. The optic nerve is violently disinserted of the retina, choroid and vitreous, and lamina cribrosa drawn from the scleral rim. We reported the case of the older male person, who attempted suicide by firing a gun in the region of the abdomen and the right temple. After the provided clinical assistance which consisted of removing the spleen and disposal stab wound to the abdomen, under the general anesthesia, followed by the operation of the right eye injured, or enucleation of the eyeball with the reconstruction of conjunctival sac. Right eye was enucleated ovum of the forensic expertise (the histopathological examination) which confirmed the complete acute section of the optic nerve. The patient was connected to the resuscitation apparatus because of the acute deep coma and after seven days he died.
\end{abstract}

Keywords: attempted suicide, optic nerve, avulsion, enu $\neg$ cleation, histopathological examination

\section{SAŽETAK}

Avulzija očnog nerva je vrlo retka, ali jedna ekstremno poražavajuća komplikacija kod povreda oka. Predstavlja odvajanje optičkog nerva od mrežnjače, horoidee i staklastog tela, i sa iščupanom rešetkastom pločom (laminom kribrozom) iz beonjače. Prikazujemo slučaj starije osobe muskog pol, koja je pokušala samoubistvo, pucanjem iz pištolja u predeo trbuha i desne slepoočnice. Nakon klinički ukazane pomoći, која se sastojala u splenektomiji i zbrinavanju probojne rane u predelu trbuha, u opštoj anesteziji, usledila je operacija desnog povredjenog oka, tj. enukleacija bulbusa sa rekonstrukcijom konjunktivalnog sakusa. Enukleisano desno oko je poslato na sudskomedicinsku ekspertizu (histopatološku verifikaciju), која je potvrdila kompletan, zadesan prekid desnog očnog nerva. Pacijent je bio priključen na reanimacijske aparate zbog akutne duboke kome i nakon sedam dana je preminuo.

Ključne reči: pokušaj samoubistva, optički nerv, avulzija, enukleacija, histopatoloski nalaz 


\section{INTRODUCTION}

Optic nerve avulsion is a very rare but extremely devastating complication of varies eye injuries. The optic nerve is violently disinserted of the retina, choroid and vitreous, and lamina cribrosa drawn from the whole scleral rim. ${ }^{1}$ Evulsion of the optic nerve is a very rare clinical form of traumatic optic neuropathy. ${ }^{2}$

Our case report is the older male person who is attempted suicide to firing a gun in the region of the abdomen and in the right temple. Right eye was enucleated ovum on the medical-forensic expertise (hystopathological examination) which confirmed the complete cessation of the optic nerve, etc.

Enucleation was performed under general doctrinal attitudes and principles, with the surgical modules, bandaged along with antibiotic-steroid medical treatment and other support local and systemic therapy in consultation with the operational and medical teams.

\section{CASE REPORT}

Our case presents a case of attempted suicide - firing a gun in the right landscape temples. The older patient was hospitalized in our Clinical Centre of Kragujevac, in the Department for Urgent Medicine. This was the second attempt of suicide leaving a number of dilemmas, both for the patient and his family.

By hetero anamnesis and clinical observations authors found an cutis lesion of right part of head with massive protrusion of the right bulb, with diagnosis - avulsio nervi optici. The left eye clinically showed regular ophthalmologic findings with dilated pupil and no response, because of the general anesthesia and the deep coma of the patient. (Figure 1)

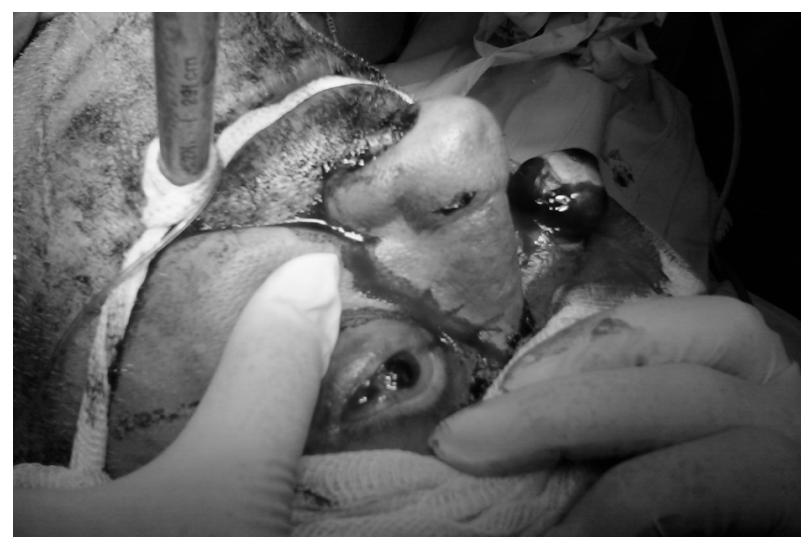

Figure 1. Traumatic avulsion of the optic nerve (attempted suicide)
After providing clinical assistance which consisted of removing the spleen and disposal stab wound to the anterior abdomen, under the general anesthesia, followed by the operation of the right injured eye, enucleation of the eye with the reconstruction the conjunctival sac, because of the application an eye protests with the magnetic implant. Justified the common general anesthesia author performed the enucleation of the right eye, where the optic nerve has already been completely truncated bullet. (Figure 2)

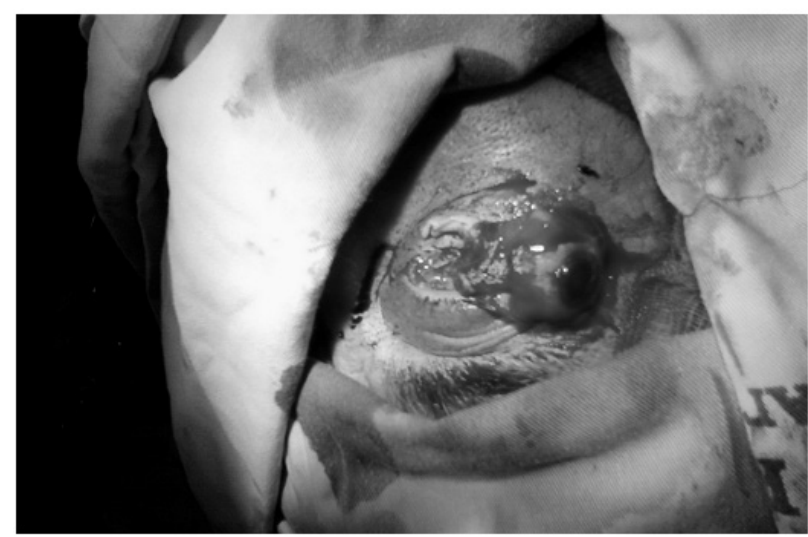

Figure 2. Enucleation of the right eye

Histopathological examination has analyzed complete discharge of the optic nerve from direct anatomical shock. Number of histopathological test is - 9168/2014. (Figure 3)

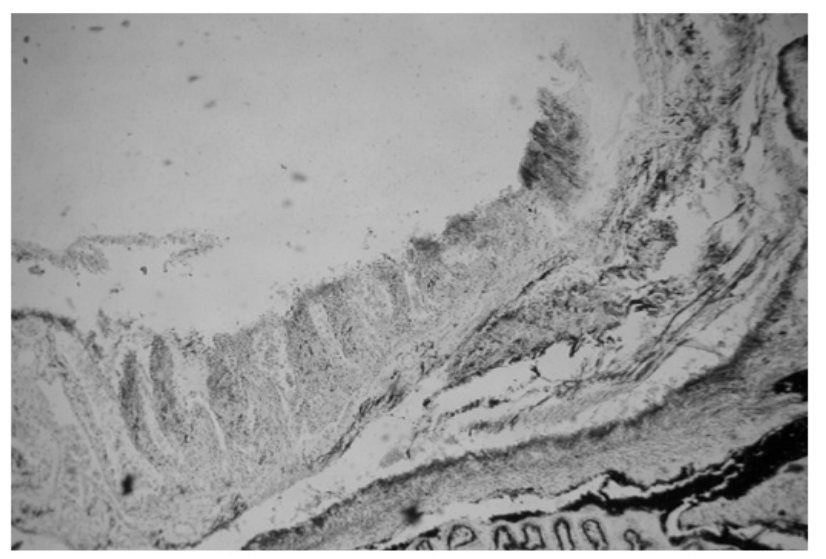

Figure 3. Histopathological examination of the right eye

We can describe this histopathological examination - on the inner side of Descemet membrane on which the epithelium camera oculi anterior, which is filled with elements of fresh bleeding; choroidal rupture with destruction corpus ciliare, ciliary muscles, dilator papillae and the muscle sphincter papillae; on the front surface of the iris discontinuous epithelium anterior iridis, flake looks; blood vessels of iris of the usual appearance, accentuated adventitia to maintain the required lumen during muscles. Due to the seriousness of his condition, the patient died after seven days in the intensive care unit and the appliances. 


\section{DISCUSSION}

Acute post-traumatic optic nerve avulsion is a very rare. The optic nerve is violently disinserted of the retina, choroid and vitreous, and lamina cribrosa drawn from the whole scleral rim. ${ }^{1}$ It is the incomplete/complete rupture of the optic nerve at the disc without damage of its sheaths occurring in association with a blunt or entering eye trauma.

Review suggests that the most common mechanism of injury is a severe rotation of the eye leading to rupture of the optic nerve fibers and anterior displacement of bulbus, possibly with deformation of posterior eye walls. ${ }^{2}$ The mechanism of eye injury in our patient was accidental, direct and complete section of retro bulbar part of the right optic nerve.

Buchwald reported a 13-year old girl with complete evulsion of optic nerve after bulbar trauma while swinging on the liana (patient had crashed into the tree). It is possible that it may occur more frequently, because it cannot be seen in blunt or also penetrating bulbar trauma (our case report) with severe intraocular cloudiness. ${ }^{3}$

Avulsion of optic nerve is the infrequent traumatic event which results in a permanent devastating loss of vision. Roberts and all presented two cases which highlight the salient features of partial and complete optic nerve avulsion. The clinical findings, including the results of B-scan ultrasonography, fluorescein angiography, and computed tomography (CT) are discussed. ${ }^{4}$ But our patient was clinically disposed as urgent operational case under general anesthesia due to poly trauma and due to suicide attempts, so there was no time to apply all diagnostic ophthalmological procedures. It was a struggle to rescue the patient's life.

Enucleation is an acceptable chirurgical modality used for end-stage ocular diseases unresponsive to another medical treatment. The most often indications for enucleation are severely traumatized eye, secondary glaucoma, intraocular malignancies, blind painful eye and phthisis bulbi with cosmetically disfigured eyes. ${ }^{5}$ The patient was a confirmed case of etiology of the optic nerve trauma, and surgical feasibility modules, so it was the indication for the enucleation of the right eye, too.

Morris described the clinical and microscopic pathologic findings in three globes that were traumatically evulsed from their orbits. Traumatic evulsion of the globe may cause the optic nerve and its sheath to be disrupted at varying distances from the eye and may involve the optic nerve and its sheath together or separately. ${ }^{6}$ In our case it was the complete and isolated avulsion of the optic nerve to the performed the histopathologically verification, too.

Four patients with evulsion of the optic nerve caused by trauma were clinically evaluated by Sanborn and al. The evulsion was complete in two of the patients and incomplete in the other two. In addition, two eyes were histopathologically studied, as was the case in our view. ${ }^{7}$

Evulsion of the nerve from the globe may be partial or complete as a result of several concussive or rotational forces. Transections of the optic nerve within the orbit generally occur after penetrating orbital injuries or surgical resection, resulting in complete blindness. Medical or surgical intervention has shown to improve the visual prognosis once such injuries occurred. ${ }^{8}$

Manual enucleation of the eyeball from the orbit during physical assault is rare. Management includes removal of such sightless eyeballs when the optic nerve and extraocular muscles are avulsed. Many authors recommend replacement of these eyeballs even though visual prognosis is nil and phthisis bulbi is expected, but which was not necessary in our case report. ${ }^{9}$

Obuchowska and al discussed the current surgical technique of enucleation with orbital implant placement, but which was not necessary in our case. ${ }^{10}$ Ophthalmologic surgeon has a difficult task to remove the dysfunctional eyeball, especially when it comes to poly trauma caused by the suicide attempt, when there is no vision on the injured eye. For justified reasons, the authors did not need any further clinical diagnostics of the right, or the left eye of the patient. What is the vision of the other eye, and what will be his future quality of life? The question was left unanswered, because the patient died. 


\section{REFERENCES}

1. Ferreira MA, Espinhosa CT, Andreo EG, Finotti IG, de Oliveira LB. Acute post-traumatic optic nerve avulsion: case report. Arq Bras Oftalmol 2007; 70(2): 337-9.

2. Buchwald HJ, Spraul CW, Wagner P, Lang GK. Optic nerve evulsion: Metaanalysis. Klin Monatsbl Augenheilkd 2001; 218(10): 635-44.

3. Buchwald HJ, Otte P, Lang GE. Evulsion of the optic nerve following blunt bulbar trauma. Klin Monatsbl Augenheilkd 2003; 220(5): 303-8.

4. Roberts SP, Schaumberg DA, Thompson P. Traumatic avulsion of the optic nerve. Optom Vis Sci 1992; 69(9): 7217.

5. Obuchowska I, Mariak Z, Sherkawey N. Clinical indications for enucleation-a review of the literature. Klin Oczna 2005; 107(1-3): 159-62.

6. Morris WR, Osborn FD, Fleming JC. Traumatic evulsion of the globe. Ophthal Plast Reconstr Surg 2002; 18(4): 261-7.

7. Sanborn GE, Gonder JR, Goldberg RE, Benson WE, Kessler S. Evulsion of the optic nerve: a clinicopathological study. Can J Ophthalmol 1984; 19(1): 10-6.

8. Rosenberg PN, Stasior OB. Optic nerve evulsion and transection. Adv Ophthalmic Plast Reconstr Surg 1987; 6(1): 63-9.

9. Taneja N, Dhaliwal U. Manual enucleation of both eyes during assault. Ophthalmic Surg Lasers Imaging 2006; 37(2): 158-60.

10. Obuchowska I, Mariak Z, Elmdhm S. Surgical technique and complications of enucleation. Klin Oczna 2005; 107(1-3): 163-6. 